\title{
ANALISIS TINGKAT KELELAHAN KERJA BERDASARKAN BEBAN KERJA FISIK PERAWAT DI INSTALASI RAWAT INAP RSU HAJI SURABAYA
}

\author{
Rizky Maharja \\ PT. Kimia Farma (Persero) Tbk. Watudakon, Jombang \\ E-mail: rizkymaharja@gmail.com
}

\begin{abstract}
Nurses are working with high expectation, especially nurses at inpatient care unit are. They are to always be ready to provide health treatment to the patients for 24 hours for 7 days. This high expectation may affect and inflicting fatigue on them. Work fatigue is a condition of activity, motivation and physical exhaustion. If nurses don't take a rest, it can accumulated work fatigue eventually drops the health condition of the nurse off. This research aims to analyze level of work fatigue based on physical workload of the nurses in Inpatient Care Unit of RSU Haji Surabaya. This observational descriptive study applied cross-sectional study design. The research was conducted nurses at ward IIIC and IVC. The respondents are 27 nurses with following the criteria of this. The research applied Kruskal Wallis test to find out the variety of the work fatigue level based on physical workload and Spearman correlation test to find out the relationship between physical workload and work fatigue. The result showed that several characteristics of most of the respondents were aged between 30 and 49 years old, female, had been working for more than 5 years, married, normal nutritional status, and low calorie intake. The result also showed the average workload and the nurses might experience moderate work fatigue. The result of inter-variables correlations indicated there were correlation between physical workloads and work fatigue and there are varieties of the work fatigue based on the physical workload.
\end{abstract}

Keywords: nurse, physical workload, work fatigue

\begin{abstract}
ABSTRAK
Pekerjaan sebagai perawat memiliki tuntutan kerja yang tinggi, khususnya perawat yang bertugas di Instalasi Rawat Inap. Hal ini disebabkan di Instalasi Rawat Inap dilakukan asuhan keperawatan 24 jam selama 7 hari. Tuntutan kerja yang tinggi dapat menyebabkan kelelahan kerja. Kelelahan kerja merupakan suatu keadaan pelemahan kegiatan, motivasi, dan aktivitas fisik. Apabila tidak dilakukan istirahat, kelelahan kerja akan terakumulasi dan mempengaruhi derajat kesehatan perawat. Penelitian ini bertujuan untuk menganalisis tingkat kelelahan kerja berdasarkan beban kerja fisik perawat Instalasi Rawat Inap di RSU Haji Surabaya. Penelitian ini merupakan penelitian observasional deskriptif dengan rancang penelitian cross sectional. Penelitian dilakukan di Instalasi Rawat Inap Ruang IIIC dan IVC. Responden penelitian adalah seluruh perawat yang memenuhi kriteria inklusi penelitian dengan jumlah 27 orang. Penelitian ini menggunakan uji Kruskal Wallis untuk mengetahui perbedaan tingkat kelelahan kerja berdasarkan beban kerja fisik dan uji Korelasi Spearman untuk mengetahui hubungan beban kerja fisik dengan kelelahan kerja. Hasil penelitian menunjukkan bahwa sebagian besar responden berumur 30 s.d 49 tahun, berjenis kelamin perempuan, memiliki masa kerja selama lebih dari 5 tahun, sudah menikah, dan memiliki status gizi kategori normal, dan memiliki asupan kalori kategori kurang. Hasil penelitian juga menunjukkan bahwa sebagian besar responden memiliki beban kerja fisik sedang dan mengalami kelelahan kerja tingkat sedang. Selain itu hasil menunjukkan bahwa beban kerja fisik dan kelelahan kerja memiliki hubungan searah dan kuat serta terdapat perbedaan tingkat kelelahan kerja berdasarkan beban kerja fisik.
\end{abstract}

Kata kunci: perawat, beban kerja fisik, kelelahan kerja

\section{PENDAHULUAN}

Tenaga kerja merupakan sumber daya yang berperan dalam melakukan pekerjaan, sehingga tenaga kerja seharusnya lebih diperhatikan dan dilindungi. Tenaga kerja bukan hanya yang bekerja di bidang perindustrian, namun juga dipelayanan jasa kesehatan, salah satunya adalah bidang keperawatan.
Keperawatan merupakan kesenian dan keilmuan yang menjawab kebutuhan pelayanan kesehatan masyarakat. (Potter dan Perry, 2009). Perawat merupakan salah satu sumber daya yang berperan penting dalam pelayanan kesehatan di rumah sakit. Pekerjaan sebagai perawat memiliki tuntutan kerja yang tinggi, khususnya perawat yang bertugas di Instalasi Rawat Inap. Hal tersebut disebabkan perawat memiliki peran dan tanggung jawab yang 
besar. Menurut Doheny dkk (1997), bahwa perawat memiliki peran pemberi layanan, pembela, edukator, komunikator, manajer, dan perkembangan karier. Selain itu, menurut Potter dan Perry (2009), bahwa perawat tidak hanya memegang tanggung jawab yang melibatkan individu saja, namun juga terhadap pengasuh dari pihak keluarga, keluarga pasien, dan komunitas.

Perawat memiliki tuntutan kerja yang tinggi, khususnya perawat yang bertugas di Instalasi Rawat Inap. Hal ini disebabkan karena di Instalasi Rawat Inap seluruh asuhan keperawatan dilakukan 24 jam selama 7 hari, sehingga menambah tanggung jawab perawat untuk melakukan asuhan keperawatan dibandingkan dengan perawat yang bertugas di instalasi lainnya. Tuntutan kerja yang tinggi tersebut menyebabkan aktivitas kerja perawat juga meningkat. Tingginya tuntutan kerja tersebut dapat mengganggu kesehatan perawat.

Menurut Setyawati (2010), bahwa kelelahan kerja terjadi akibat penumpukan asam laktat. Pada saat bekerja tubuh membutuhkan energi. Energi tersebut diperoleh dari hasil pemecahan glikogen.

Selain energi, asam laktat merupakan salah satu hasil dari pemecahan glikogen. Saat otot berkontraksi, maka akan terjadi penumpukan asam laktat. Asam laktat ini menghambat kerja otot dan menyebabkan rasa lelah.

Kelelahan kerja adalah suatu kondisi melemahnya kegiatan, movivasi, dan kelelahan fisik untuk melakukan kerja. Menurut Cameron (1973) dalam Setyawati (2010), bahwa kelelahan kerja menyangkut penurunan kinerja fisik, adanya perasaan lelah, penurunan motivasi, dan penurunan produktivitas kerja. Menurut Suma'mur (2009), bahwa kelelahan merupakan penurunan ketahanan dan daya tubuh untuk melakukan pekerjaan. Menurut Setyawati (2010), bahwa kelelahan kerja tidak dapat didefinisikan tetapi dapat dirasakan sehingga penentuan kelelahan kerja dapat diketahui secara subjektif berdasarkan perasaan yang dialami tenaga kerja. Menurut Suma'mur (2009), bahwa kelelahan kerja tidak hanya terjadi pada akhir waktu kerja, namun juga dapat terjadi sebelum bekerja.

Kelelahan kerja tidak hanya dialami oleh tenaga kerja yang bekerja di bidang industri, namun juga di bidang pelayanan kesehatan, contohnya perawat. Hal ini dibuktikan dari hasil penelitian Perwitasari (2014), bahwa sebagian besar perawat diRSUD dr. Mohamad Soewandhie Surabaya mengalami kelelahan kerja sedang. Penelitian serupa yang dilakukan oleh Widayanti (2010), menunjukkan sebagian besar perawat di Ruang Mawar Kuning IRNA RSUD Kabupaten Sidoarjo mengalami kelelahan. Selain itu penelitian yang dilakukan oleh Nurhayati (2006), menunjukkan bahwa perawat di Instalasi Rawat Inap RSU Unit Swadana Daerah Dr. R. Sosodoro Djatikoesoemo Kabupaten Bojonegoro mengalami kelelahan kerja pada tingkat cukup lelah dan sangat lelah. Penelitian serupa juga dilakukan oleh Zuliana (2013), bahwa dari sebagian besar responden perawat di Instalasi Rawat Inap RSUD Dr. Iskak Tulungagung mengalami tingkat kelelahan ringan, sedang, dan berat.

Berbagai penelitian tersebut menunjukkan bahwa kelelahan kerja dapat dengan mudah menyerang perawat, mengingat bahwa perawat yang bertugas di Instalasi Rawat Inap memiliki tanggung jawab yang lebih besar dan lebih baik dengan bekerja 24 jam selama 7 hari dengan sistem shift kerja. Selain itu, beban kerja perawat dapat semakin bertambah jika perawat melakukan shift terusan, yaitu dalam sehari mengambil dua kali shift. Selain menambah beban kerja fisik, hal tersebut juga dapat menyebabkan terjadinya peningkatan kelelahan kerja karena berkurangnya waktu tidur dan mengganggu irama biologis tubuh.

Apabila kelelahan kerja tidak segera ditangani dan segera beristirahat, maka akan terjadi akumulasi kelelahan dalam sehari, sehingga dapat berdampak lebih parah terhadap kesehatan. Menurut Tarwaka (2010), bahwa risiko dari kelelahan kerja yaitu: motivasi kerja menurun, performansi rendah, kualitas kerja rendah, banyak terjadi kesalahan, produktivitas kerja rendah, stress akibat kerja, penyakit akibat kerja, cedera, dan terjadi kecelakaan kerja. Sedangkan menurut Setyawati (2010), bahwa dampak dari kelelahan kerja adalah prestasi kerja menurun, badan terasa tidak enak, semangat kerja menurun, dan menurunkan produktivitas kerja.

Menurut Setyawati (2010), bahwa kelelahan kerja menyebabkan terjadi kecelakaan kerja. Menurut Suma'mur (2009) bahwa kecelakaan kerja membawa kerugian bagi tempat kerja, baik dari segi biaya, waktu, produktivitas maupun tenaga. Kelelahan kerja yang dialami perawat harus menjadi perhatian bagi pihak rumah sakit. Hal itu disebabkan perawat memiliki peran penting bagi pasien rumah sakit.

Menurut Tarwaka (2010), bahwa salah satu penyebab kelelahan kerja adalah beban kerja fisik. Beberapa penelitian menunjukkan bahwa gangguan kelelahan kerja terkait dengan beban kerja sering dialami oleh perawat. Hal ini didukung 
oleh penelitian yang dilakukan oleh Rahmawati (2006), bahwa ada hubungan beban kerja dengan kelelahan kerja sebesar 0,001 di RSUD Dr. Harjono Kabupaten Ponorogo. Penelitian tersebut didukung oleh berbagai penelitian yang meneliti tentang beban kerja fisik perawat. Berdasarkan penelitian yang dilakukan oleh Dewi (2008), menunjukkan bahwa perawat di RS Adi Husada Undaan Wetan Kota Surabaya memiliki beban kerja fisik kategori sedang. Penelitian serupa juga dilakukan oleh Dianasari (2014), bahwa beban kerja fisik yang dialami perawat di Instalasi Rawat Inap termasuk ke dalam kategori ringan dan sedang.

Menurut Suma'mur (2009), bahwa aktivitas kerja yang dilakukan melibatkan semua organ tubuh, otot, dan otak, sehingga peningkatan aktivitas kerja mengindikasikan terjadi peningkatan beban kerja. Beban kerja terdiri dari dua, yaitu beban kerja fisik dan beban kerja mental. Menurut Suma'mur (2009), bahwa beban dari setiap pekerjaan dapat berupa beban kerja fisik, mental dan atau social. Menurut Rodahl (1989), Adiputra (1998), dan Manuaba (2000) dalam Tarwaka (2010), bahwa beban kerja dan tuntutan kerja dipengaruhi oleh berbagai faktor internal dan eksternal. Faktor eksternal yang mempengaruhi beban kerja adalah tugas-tugas, organisasi kerja, lingkungan kerja baik lingkungan kerja fisik, kimiawi, biologis, dan psilologis, sedangkan faktor internal yang mempengaruhi beban kerja adalah faktor somatis dan faktor psikis.

Pada beban kerja fisik diperlukan kerja otot, jantung, dan paru, sehingga jika beban kerja fisik tinggi maka kerja otot, jantung, dan paru akan semakin tinggi juga, begitu pula sebaliknya. Menurut Tarwaka (2010), bahwa beban kerja fisik melibatkan penggunaan otot atau memerlukan usaha fisik untuk melakukan pekerjaan tersebut. Setiap melakukan aktivitas kerja, maka mengakibatkan perubahan fungsi faal pada organ tubuh, diantaranya adalah konsumsi oksigen atau kebutuhan oksigen, laju detak jantung, peredaran udara atau ventilasi paruparu, temperature tubuh, konsentrasi asam laktat dalam darah, komposisi kimia dalam darah dan jumlah air seni, tingkat penguapan melalui keringat, dan lain-lain (Tarwaka, 2010).

Berdasarkan hal tersebut maka salah satu cara untuk mengetahui beban kerja fisik tenaga kerja yaitu dengan menghitung denyut nadi. Menurut Kurniawan (1995) dalam Tarwaka (2010), bahwa denyut nadi memiliki kepekaan yang cukup tinggi terhadap perubahan beban kerja yang diterima oleh tubuh. Selain itu menurut Tarwaka (2010), bahwa beban kerja fisik melibatkan otot dalam bekerja, sehingga dapat meningkatkan denyut nadi.

Menurut Tarwaka (2010), beban kerja harus seimbang dengan kemampuan dan keterbatasan manusia. Selain itu menurut Suma'mur (2009), bahwa kemampuan kerja setiap orang berbedabeda yang dipengaruhi oleh banyak faktor. Beban kerja fisik yang tidak sesuai, maka dapat berdampak buruk pada kesehatan perawat. Menurut Suma'mur (2009), bahwa beban kerja fisik merupakan indikator yang menentukan lama waktu seseorang dapat bertahan dan bekerja sesuai dengan kemampuan yang dimiliki. Oleh karena itu, beban kerja fisik merupakan salah satu aspek yang perlu dipertimbangkan untuk menjaga kesehatan perawat. Apabila beban kerja fisik tidak sesuai dengan kemampuan kerja perawat, maka dapat mengganggu kesehatan perawat. Terganggunya kesehatan tenaga kerja dapat menurunkan kemampuan kerja sehingga menurunkan produktivitas (Suma'mur, 2009).

Rumah sakit sebaiknya segera melakukan manajemen kelelahan kerja yang terintegrasi dengan manajemen K3 di rumah sakit (K3RS). Menurut Setyawati (2010), bahwa manajemen kelelahan kerja merupakan hal yang penting untuk diperhatikan dan dilaksanakan untuk mencegah dan menghambat dampak negatif dari kelelahan kerja. Manajemen kelelahan kerja dapat bersifat jangka pendek maupun jangka panjang. Jangka pendek dapat berupa pendidikan dan pelatihan mengenai K3 kepada pihak direksi hingga struktur paling bawa, sedangkan jangka panjang dapat berupa promosi kesehatan. Manajemen kelelahan kerja yang berkaitan dengan manajemen K3 harus dilaksanakan dan terintegrasi oleh seluruh pihak yang terkait. Hal ini dilakukan agar dampak dari manajemen kelelahan kerja dapat dirasakan secara menyeluruh.

RSU Haji Surabaya merupakan rumah sakit rujukan provinsi dan termasuk rumah sakit tipe B pendidikan. Salah satu pelayanan yang dilakukan di RSU Haji Surabaya adalah pelayanan Instalasi Rawat Inap. Ruang Marwah merupakan salah satu Instalasi Rawat Inap yang ada di RSU Haji Surabaya. Ruang Marwah terbagi atas ruang IC, IIC, IIIC, dan IVC. Pasien di Ruang Marwah IC, IIC, IIIC, dan IVC mengalami peningkatan dari tahun ke tahun yang dibuktikan dengan Bed Occupancy Rate (BOR) atau angka penggunaan tempat tidur. Berdasarkan studi pendahuluan yang dilakukan capaian BOR pada tahun 2007 s.d. 2014 di Ruang IIIC dan IVC cenderung mengalami peningkatan dan mencapai $78,20 \%$ dan $74,32 \%$. Capaian BOR 
tersebut merupakan yang tertinggi di antara ruangan yang ada di Ruang Marwah RSU Haji Surabaya. Ruang IIIC adalah ruang Instalasi Rawat Inap yang memiliki tempat tidur adalah 28 ruang perawatan khusus pasien JPS, JKN, dan Jamsostek berjenis kelamin laki-laki kelas III dan umum kelas II dan III, sedangkan ruang IVC merupakan ruang Instalasi Rawat Inap yang memiliki tempat tidur adalah 28 ruang perawatan khusus pasien JPS, JKN, dan Jamsostek berjenis kelamin perempuan kelas III dan umum kelas II dan III.

Peningkatan capaian BOR tersebut menunjukkan bahwa terjadi peningkatan penggunaan layanan Instalasi Rawat Inap di RSU Haji Surabaya. Hal ini menunjukkan bahwa aktivitas kerja perawat di ruang tersebut juga mengalami peningkatan. Selain itu berdasarkan Laporan Akuntabilitas Manajemen Keperawatan Instalasi Rawat Inap Tahun 2011 menunjukkan bahwa sebesar $78,57 \%$ responden dari perawat terbebani secara fisik dan sebanyak $81 \%$ responden mengalami beban kerja subjektif kategori tinggi. Beban kerja subjektif adalah beban kerja tambahan yang diperoleh perawat dari pekerjaan yang berhubungan maupun tidak berhubungan dengan profesi sebagai perawat.

Penelitian ini bertujuan untuk menganalisis tingkat kelelahan kerja berdasarkan beban kerja fisik perawat Instalasi Rawat Inap di RSU Haji Surabaya. Beban kerja fisik yang dimaksud adalah beban kerja yang berasal dari aktivitas kerja yang dilakukan perawat. Kelelahan kerja yang dimaksud adalah kelelahan kerja yang dialami perawat akibat dari pekerjaan yang dilakukan.

Manfaat penelitian ini bagi rumah sakit yaitu dapat membantu memberikan gambaran tentang beban kerja fisik, asupan kalori, dan kelelahan kerja perawat, sehingga dapat menjadi bahan pertimbangan dalam membuat kebijakan rumah sakit, sedangkan manfaat bagi bidang keperawatan yaitu membantu memberikan gambaran mengenai beban kerja fisik dan kelelahan kerja perawat, sehingga asuhan keperawat dapat dilakukan dengan baik tanpa mengalami kelelahan kerja dan gangguan kesehatan lainnya.

\section{METODE}

Penelitian ini merupakan penelitian observasional deskriptif dengan rancang penelitian cross sectional. Penelitian ini dilakukan di Instalasi Rawat Inap Ruang IIIC dan IVC di RSU Haji Surabaya. Populasi adalah seluruh perawat yang bertugas di Instalasi Rawat Inap Ruang IIIC dan IV di RSU Haji Surabaya dengan jumlah 27 orang.

Pengambilan perawat sebagai responden disesuaikan dengan kriteria inklusi sebagai berikut: tidak memiliki riwayat penyakit, tidak menderita dan memiliki risiko anemia, tidak merokok, responden wanita tidak haid, tidak hamil, dan tidak menyusui, sehat, dan bersedia mengikuti penelitian. Cara pengambilan responden adalah total populasi. Responden akan diberikan kuesioner untuk mengetahui kesesuaian dengan kriteria inklusi. Jika responden yang terpilih tidak memenuhi kriteria inklusi, maka tidak dapat dijadikan sebagai responden dalam penelitian ini.

Variabel bebas dalam penelitian ini adalah asupan kalori, sedangkan variabel terikat adalah kelelahan kerja. Adapun definisi operasional dari beban kerja fisik adalah beban dari aktivitas fisik yang diterima tenaga kerja dari pekerjaan yang dilakukan, sedangkan kelelahan kerja adalah suatu keadaan akibat kerja yang dilakukan oleh tenaga kerja berupa penurunan kemampuan maupun perasaan lelah untuk melakukan suatu kegiatan berdasarkan metode subjektif yang dirasakan responden.

Cara pengumpulan data primer melalui pengisian kuesioner karakteristik individu untuk mempelajari karakteristik individu dan sebagai syarat untuk melihat kesesuaian dengan kriteria inklusi, menghitung denyut nadi kerja sebanyak 6 kali yaitu sebelum bekerja, pada saat bekerja yaitu pada menit ke-5, ke-10, ke-60, ke-120, dan pada akhir jam kerja, dan mengisi kuesioner Industrial Fatigue Research Committee (IFRC) untuk mempelajari kelelahan kerja, sedangkan pengumpulan data sekunder dilakukan untuk mendapatkan gambaran umum RSU Haji dan daftar dinas perawat di Instalasi Rawat Inap Ruang IIIC dan IVC RSU Haji Surabaya.

Data hasil perhitungan beban kerja fisik dikategorikan menjadi ringan, sedang, berat, sangat berat, dan sangat berat sekali yang selanjutnya dibuat tabel frekuensi. Data hasil perhitungan kelelahan kerja dikategorikan menjadi rendah, sedang, tinggi, dan sangat tinggi yang selanjutnya dibuat tabel frekuensi. Penelitian ini menggunakan uji Kruskal Wallis untuk mengetahui ada-tidaknya perbedaan tingkat kelelahan kerja berdasarkan beban kerja fisik. Selain itu, digunakan pula uji Korelasi Spearman untuk mengetahui ada-tidaknya hubungan antara beban kerja fisik dengan kelelahan kerja. Hasil data disajikan dalam bentuk tabel frekuensi dan tabulasi silang. 


\section{HASIL}

\section{Karakteristik Responden}

Karakteristik responden meliputi: umur, jenis kelamin, masa kerja, status pernikahan, status gizi dan asupan kalori.

Tabel 1. Distribusi Karakteristik Responden di Instalasi Rawat Inap Ruang IIIC dan IVC RSU Haji Surabaya Tahun 2015

\begin{tabular}{lcc}
\hline $\begin{array}{c}\text { Karakteristik } \\
\text { Responden }\end{array}$ & $\begin{array}{c}\text { Jumlah } \\
\text { (orang) }\end{array}$ & $\begin{array}{c}\text { Persentase } \\
(\%)\end{array}$ \\
\hline Umur & & \\
19 s.d. 29 tahun & 13 & 48,15 \\
30 s.d 49 tahun & 14 & 51,85 \\
50 s.d 64 tahun & 0 & 0 \\
Jenis Kelamin & & \\
$\quad$ Laki-laki & 5 & 18,52 \\
$\quad$ Perempuan & 22 & 81,48 \\
Masa Kerja & & \\
$\leq 5$ tahun & 12 & 44,44 \\
$\quad$ 5 tahun & 15 & 55,56 \\
Status Pernikahan & & \\
Belum menikah & 6 & 22,22 \\
$\quad$ Sudah menikah & 21 & 77,78 \\
Status Gizi & & \\
Kurus tingkat berat & 0 & 0 \\
Kurus tingkat ringan & 3 & 11,11 \\
Normal & 17 & 62,96 \\
Gemuk tingkat ringan & 3 & 11,11 \\
$\quad$ Gemuk tingkat berat & 4 & 14,81 \\
Asupan Kalori & & \\
Kurang & 12 & 44,4 \\
Cukup & 10 & 37,0 \\
Lebih & 5 & 18,5 \\
\hline
\end{tabular}

Berdasarkan Tabel 1 dapat disimpulkan bahwa sebanyak $14(51,85 \%)$ responden memiliki rentang umur 30 s.d. 49 tahun. Umur tersebut menandakan bahwa sebagian besar responden termasuk pada usia produktif dan siap menjalani pekerjaan baik secara psikologis maupun fisik. Selain itu dapat diketahui pula bahwa sebagian besar responden berjenis kelamin perempuan yaitu $22(81,48 \%)$ responden.

Masa kerja terbanyak yang dimiliki responden adalah lebih dari 5 tahun yaitu sebanyak $15(55,56 \%)$ responden. Masa kerja tersebut membuktikan bahwa sebagian besar responden telah memiliki banyak pengalaman di bidang asuhan keperawatan, sehingga mampu dan memiliki mekanisme coping tersendiri dalam mengatasi masalah yang muncul dalam pekerjaan keperawatan. Hasil juga menunjukkan bahwa sebagian besar responden sudah menikah yaitu sebanyak $21(77,78 \%)$ responden. Status sudah menikah ini menjadikan perawat memiliki beban tambahan selain beban utama dari pekerjaan keperawatan. Selain itu, sebagian besar responden yaitu sebanyak $17(62,96 \%)$ memiliki status gizi kategori normal yang membuktikan bahwa komposisi zat gizi dan kalori di dalam tubuh perawat dalam kondisi baik dan sesuai kadarnya. Asupan kalori yang dimiliki perawat berada pada kategori kurang yaitu sebesar $12(44,4 \%)$ responden yang berarti bahwa konsumsi makanan perawat masih tergolong kurang.

\section{Beban Kerja Responden}

Distribusi responden berdasarkan beban kerja fisik adalah sebagai berikut:

Tabel 2. Beban Kerja Fisik Responden di Instalasi Rawat Inap Ruang IIIC dan IVC RSU Haji Surabaya Tahun 2015

\begin{tabular}{lcc}
\hline \multicolumn{1}{c}{ Beban Kerja Fisik } & $\begin{array}{c}\text { Jumlah } \\
\text { (orang) }\end{array}$ & $\begin{array}{c}\text { Persentase } \\
\text { (\%) }\end{array}$ \\
\hline Ringan & 7 & 25,9 \\
Sedang & 20 & 74,1 \\
\hline Jumlah & 27 & 100 \\
\hline
\end{tabular}

Berdasarkan Tabel 2 dapat diketahui bahwa sebagian besar responden memiliki beban kerja fisik kategori sedang yaitu sebanyak yaitu sebanyak 20 $(74,1 \%)$ memiliki beban kerja fisik kategori ringan. Beban kerja fisik kategori sedang menunjukkan bahwa aktivitas kerja yang dimiliki perawat di Instalasi Rawat Inap banyak dan beragam.

\section{Kelelahan Kerja Responden}

Distribusi responden berdasarkan kelelahan kerja adalah sebagai berikut:

Tabel 3. Kelelahan Kerja Responden di Instalasi Rawat Inap Ruang IIIC dan IVC RSU Haji Surabaya Tahun 2015

\begin{tabular}{lcc}
\hline \multicolumn{1}{c}{ Kelelahan Kerja } & $\begin{array}{c}\text { Jumlah } \\
\text { (orang) }\end{array}$ & $\begin{array}{c}\text { Persentase } \\
\text { (\%) }\end{array}$ \\
\hline Ringan & 10 & 37,0 \\
Sedang & 14 & 51,9 \\
Tinggi & 3 & 11,1 \\
Jumlah & 27 & 100 \\
\hline
\end{tabular}

Berdasarkan Tabel 3 dapat diketahui bahwa sebagian besar responden mengalami kelelahan kerja tingkat sedang yaitu sebanyak $14(51,9 \%)$ responden. 
Kelelahan kerja tingkat sedang ini menunjukkan bahwa perawat mudah mengalami kelelahan kerja dengan tingkat yang cukup tinggi.

\section{Tingkat Kelelahan Kerja Berdasarkan Beban Kerja Fisik}

Berdasarkan uji yang dilakukan, diperoleh koefisien korelasi sebesar 0,428 yang menunjukkan bahwa beban kerja fisik dan kelelahan kerja memiliki hubungan yang kuat dan searah. Hal ini dibuktikan dengan Tabel 4. Berdasarkan Tabel 4 dapat diketahui bahwa responden dengan beban kerja ringan mengalami tingkat kelelahan kerja tingkat ringan sebanyak $5(71,4 \%)$ responden dan kelelahan kerja tingkat sedang sebanyak $2(28,6 \%)$ responden, sedangkan responden dengan beban kerja fisik kategori sedang mengalami kelelahan kerja ringan sebanyak $5(25,0 \%)$ responden dan kelelahan kerja tingkat sedang sebanyak $12(60,0 \%)$ responden. Persentase tertinggi diperoleh oleh responden dengan beban kerja fisik sedang yang mengalami kelelahan kerja tingkat sedang. Hal ini berarti bahwa beban kerja fisik berbanding lurus dengan peningkatan kelelahan kerja bahwa semakin meningkatnya beban kerja fisik, maka kelelahan kerja juga akan mengalami peningkatan.

Adapun distribusi responden berdasarkan kelelahan kerja berdasarkan beban kerja fisik dapat diketahui dari tabel berikut ini:

Tabel 4. Distribusi Tingkat Kelelahan Kerja Berdasarkan Beban Kerja Fisik di Ruang IIIC dan IVC RSU Haji Surabaya Tahun 2015

\begin{tabular}{llrl}
\hline $\begin{array}{r}\text { Kelelahan } \\
\text { Kerja }\end{array}$ & & & \\
Beban & Ringan & Sedang & Tinggi \\
Kerja Fisik & & & \\
\hline Ringan & $5(71,4 \%)$ & $2(28,6 \%)$ & $0(0,0 \%)$ \\
Sedang & $5(25,0 \%)$ & $12(60,0 \%)$ & $3(100 \%)$ \\
\hline
\end{tabular}

\section{Perbedaan Tingkat Kelelahan Kerja Berdasarkan Beban Kerja Fisik}

Berdasarkan nilai mean rank pada Tabel 5 dapat disimpulkan bahwa terdapat perbedaan tingkat kelelahan kerja berdasarkan beban kerja fisik. Perbedaan tingkat kelelahan kerja berdasarkan beban kerja fisik membuktikan bahwa beban kerja fisik berpengaruh terhadap tingkat kelelahan kerja.
Tabel 5. Perbedaan Tingkat Kelelahan Kerja Berdasarkan Beban Kerja Fisik di Ruang IIIC dan IVC RSU Haji Surabaya Tahun 2015

\begin{tabular}{lcc}
\hline \multicolumn{1}{c}{ Kelelahan Kerja } & $\begin{array}{c}\text { Jumlah } \\
\text { (orang) }\end{array}$ & Mean Rank \\
\hline Ringan & 10 & 10,75 \\
Sedang & 14 & 15,57 \\
Tinggi & 3 & 17,50 \\
\hline Total & $\mathbf{2 7}$ & \\
\hline
\end{tabular}

\section{PEMBAHASAN}

Menurut Tarwaka (2010), bahwa salah satu penyebab kelelahan kerja adalah aktivitas kerja. Adanya aktivitas kerja menyebabkan timbulnya beban kerja dari aktivitas yang dilakukan tersebut. Beban kerja merupakan suatu beban atau tanggungan yang diperoleh dari aktivitas kerja yang dilakukan. Beban kerja dapat berupa beban kerja fisik dan beban kerja mental. Pada beban kerja fisik melibatkan kerja otot atau mempengaruhi fungsi faal tubuh manusia (Tarwaka, 2010).

Hasil penelitian menunjukkan bahwa beban kerja fisik perawat berada pada kategori sedang. Beban kerja fisik perawat yang termasuk kategori sedang disebabkan karena perawat memiliki aktivitas kerja yang banyak dan beragam. Secara umum, tugas khusus perawat di Instalasi Rawat Inap RSU Haji Surabaya adalah memberikan pelayanan perawatan secara langsung berdasarkan proses perawatan, melaksanakan tindakan perawatan dan mengevaluasi sesuai masalah pasien, melaksanakan programprogram medik dengan penuh tanggung jawab antara lain pemberian obat, pemeriksaan labarot, radiologi, dan persiapan pasien yang akan operasi, memperhatikan keseimbangan kebutuhan fisik, mental, dan spiritual pasien antara lain mengurangi penderitaan pasien, memberikan rasa aman, dan nyaman, serta melakukan komunikasi terapeutik, melatih pasien untuk menolong dirinya sesuai kemampuannya yang tidak bertentangan dengan pengobatannya, memberikan pertolongan segera kepada pasien gawat atau sakratul maut, memelihara kebersihan, keamanan, kenyamanan dan keindahan ruangan, mendampingi dokter visite dan mencatat program yang akan dilaksanakan, melaporkan segala sesuatu mengenai keadaan pasien baik secara lisan maupun tulisan kepada dokter, membuat laporan harian, menciptakan dan memelihara hubungan baik dengan pasien, keluarga pasien, dokter, dan anggota tim yang lain, melakukan serah-terima tanggung 
jawab secara lisan dan tulisan, dan membantu kepala ruangan dalam ketatalaksanaan ruangan secara administrasi.

Berbagai tugas tersebut menggambarkan banyaknya aktivitas kerja perawat di Instalasi Rawat Inap yang menunjukkan bahwa perawat juga rentan terhadap beban kerja fisik yang tinggi. Penelitian ini didukung oleh penelitian yang dilakukan oleh Perwitasari (2014), bahwa beban kerja fisik perawat di RSUD dr. Mohamad Soewandhie termasuk beban kerja fisik kategori sedang.

Hasil penelitian juga menunjukkan bahwa kelelahan kerja perawat berada pada kategori sedang. Kelelahan kerja kategori sedang ini berhubungan dengan beban kerja fisik perawat yang dilihat dari aktivitas kerja yang dimiliki perawat. Selain itu, perawat yang bekerja di Instalasi Rawat Inap memiliki sistem kerja gilir (shift kerja). Instalasi Rawat Inap Ruang IIIC dan IVC RSU Haji Surabaya memiliki shift pagi (pukul 07.00 s.d. 14.00 WIB) dan shift sore (14.00 s.d. 21.00 WIB) dengan lama kerja 7 jam serta shift malam (21.00 s.d. 07.00 WIB) dengan lama kerja 10 jam. Perbedaan lama kerja ini juga menentukan tingkat kelelahan kerja. Menurut Setyawati (2010), bahwa shift kerja dapat menimbulkan kelelahan kerja karena kurangnya waktu tidur, khususnya pada shift malam. Hal ini didukung oleh Suma'mur (2009), bahwa kelelahan kerja pada shift malam relatif lebih besar dibandingkan dengan shift lainnya. Penelitian yang dilakukan oleh Maharja (2015), bahwa shift kerja dan kelelahan kerja memiliki hubungan searah dan kuat serta terdapat perbedaan tingkat kelelahan kerja berdasarkan shift kerja.

Hasil penelitian juga menunjukkan bahwa beban kerja fisik dan kelelahan kerja memiliki hubungan searah dan kuat. Hal tersebut disebabkan semakin tinggi beban kerja fisik yang diberikan, maka semakin tinggi kelelahan kerja yang dialami (Suma'mur, 2009). Pada beban kerja fisik melibatkan kerja otot atau mempengaruhi fungsi faal tubuh manusia. Beban kerja fisik yang semakin tinggi dapat menurunkan kekuatan dan kecepatan kontraksi otot yang menunjukkan kerja otot semakin melemah. Penurunan kerja otot ini dapat menyebabkan kelelahan kerja. Hal ini sesuai dengan penelitian yang dilakukan oleh Rahayu (2013), bahwa terdapat hubungan yang cukup berarti antara beban kerja fisik dengan kelelahan kerja. Selain itu, penelitian yang dilakukan Hariyati (2011), bahwa terdapat pengaruh beban kerja fisik terhadap terjadinya kelelahan kerja. Hal ini didukung oleh penelitian yang dilakukan
Wati dan Haryono (2011), bahwa beban kerja memiliki hubungan bermakna dengan kelelahan kerja pada tenaga kerja. Selain itu, penelitian yang dilakukan oleh Utami (2012), bahwa beban kerja memiliki hubungan dengan kelelahan kerja sebesar 0,032 . Penelitian ini juga didukung oleh penelitian Ramayanti (2015), bahwa beban kerja fisik dan kelelahan kerja memiliki hubungan berkategori sedang dan memiliki hubungan bermakna. Studi serupa juga dilakukan oleh Maharja (2015), bahwa beban kerja fisik memiliki hubungan searah dan kuat dengan kejadian kelelahan kerja.

Menurut Nurmianto (1998), bahwa peningkatan beban kerja fisik selaras dengan peningkatan konsumsi oksigen. Saat mencapai titik maksimum maka konsumsi oksigen mengalami penurunan dan bermanifestasi menyebabkan rasa lelah akibat peningkatan asam laktat. Hal ini didukung oleh Nawawinetu (2012), bahwa salah satu penyumbang terjadinya kelelahan kerja adalah peningkatan beban kerja fisik. Hal tersebut berkaitan dengan peningkatan konsumsi oksigen atau kebutuhan oksigen. Jika beban kerja fisik melebihi asupan oksigen maksimum, maka menyebabkan penurunan suplai oksigen ke otot sehingga akan terjadi proses anaerob dalam memecah glikogen otot menjadi energi dan asam laktat. Asam laktat bersama air kemudian menumpuk di otot sehingga menjadikan otot bengkak dan akan sulit berkontraksi. Hal tersebut akan menimbulkan gejala rasa lelah. Selain itu, berdasarkan penelitian diperoleh bahwa sebagian besar responden memiliki asupan kalori kurang. Kurangnya asupan kalori menyebabkan tubuh kekurangan glukosa. Hal ini menyebabkan tubuh memecah glikogen. Pemecahan glikogen menghasilkan asam laktat, sehingga jika asupan kalori berkurang makan asam laktat di tubuh akan menumpuk. Menurut Santoso (2004), bahwa penumpukan asam laktat tersebut menimbulkan rasa lelah akibat otot sulit berkontraksi. Hal ini sejalan dengan penelitian yang dilakukan oleh Nugraha (2009), bahwa dari semua tenaga kerja di Instalasi Gizi Rumah Sakit Bhayangkara Pusdik Gasum Porong, sebagian besar belum terpenuhi kebutuhan kalorinya sehingga mengalami kelelahan subyektif ringan. Selain itu, penelitian ini juga sejalan dengan penelitian yang dilakukan Sari (2014), bahwa asupan kalori memiliki hubungan dengan kelelahan kerja. Penelitian tersebut didukung oleh Maharja (2015), bahwa asupan kalori memiliki hubungan searah dan kuat dengan kejadian kelelahan kerja, hasil penelitian tersebut juga menunjukkan bahwa perawat 
dengan asupan kalori yang berbeda-beda memiliki kelelahan kerja yang berbeda pula.

Menurut Suma'mur (2009), bahwa otot bekerja dengan cara kontraksi (mengerut) dan melemas. Saat otot berkontraksi, darah yang berada di antara serat otot maupun luar pembuluh darah akan terjepit. Darah yang terjepit tersebut akan menghambat peredaran darah. Hal ini dapat mengganggu pertukaran zat dalam tubuh dan juga menyebabkan oksigen yang terbawa oleh darah menjadi berkurang, sehingga tubuh tidak memiliki cukup oksigen. Berkurangnya jumlah oksigen di dalam tubuh, akan menyebabkan produksi asam laktat bertambah sehingga menimbulkan kelelahan kerja. Menurut Nurmianto (1998), bahwa produksi asam laktat diperoleh ketika tubuh kekurangan oksigen sehingga tubuh memenuhi kebutuhan energi dengan cara memecah glikogen.

Hasil penelitian juga menunjukkan bahwa terdapat perbedaan tingkat kelelahan kerja berdasarkan beban kerja fisik. Hal ini dibuktikan dengan hasil mean rank. Adanya perbedaan tingkat kelelahan kerja berdasarkan beban kerja fisik disebabkan perawat memiliki aktivitas kerja yang berbeda satu sama lain. Perbedaan kelelahan kerja yang dialami oleh perawat juga disebabkan karena perbedaan beban kerja fisik. Hal ini disebabkan aktivitas perawat pada satu waktu terkadang berbeda, misalnya pada satu waktu ada yang melakukan konsultasi dokter, menemani dokter visite, melakukan injeksi, menyiapkan obat, mengambil darah, memeriksa pasien, edukasi keluarga pasien, dan lain-lain. Perbedaan aktivitas kerja ini menyebabkan beban kerja fisiknya juga berbeda karena masing-masing pekerjaan memiliki beban kerja fisik yang berbeda pula (Tarwaka, 2010).

Hasil penelitian ini juga menunjukkan bahwa kelelahan kerja tingkat sedang banyak dialami oleh perawat yang memiliki beban kerja fisik kategori sedang. Menurut Setyawati (2010), bahwa beban kerja fisik yang diberikan dapat berpengaruh pada tingkat kelelahan. Kelelahan kerja sedang lebih banyak dialami oleh perawat dengan beban kerja fisik kategori sedang disebabkan karena beban kerja fisik berhubungan dengan terjadinya kelelahan kerja (Maharja, 2015). Selain itu menurut Rodahl dkk (1989) dalam Tarwaka (2010), bahwa kelelahan kerja juga dipengaruhi oleh tugas fisik yang berkaitan dengan tata ruang, sarana kerja, kondisi beban kerja, cara angkat-angkut, dan lain-lain mempengaruhi kelelahan kerja seseorang.
Akumulasi beban kerja fisik baik dari segi tugas fisik, beban kerja utama, dan beban kerja tambahan dapat memperparah tingkat kelelahan kerja. Menurut Tarwaka (2010), bahwa jika otot berkontraksi melebih $20 \%$ dari kekuatan otot maksimun, maka peredaran darah ke otot terhambat. Terhambatnya peredaran darah ke otot mengakibatkan suplai oksigen berkurang, sehingga metabolisme terhambat dan menyebabkan penimbunan asam laktat yang menimbulkan rasa nyeri pada otot

Menurut Siswanto (1991), bahwa jika tenaga kerja bekerja dengan pengerahan tenaga maksimum maka dapat memperpendek lamanya waktu kerja. Selain itu menurut Suma'mur (2009), bahwa jika bekerja terus-menerus tanpa melakukan istirahat dapat memperparah tingkat kelelahan kerja. Kondisi ini jika dibiarkan, maka kelelahan kerja akan terakumulasi dan dapat menurunkan derajat kesehatan perawat, sehingga pihak rumah sakit perlu membuat kebijakan terkait manajemen kelelahan kerja. Menurut Setyawati (2010), bahwa salah satu upaya untuk mencegah, menanggulangi, dan mengobati kelelahan kerja adalah melalui manajemen kelelahan kerja. Kelelahan kerja dapat diatasi melalui tindakan preventif, kuratif, dan rehabilitatif. Manajemen kelelahan kerja dapat dilakukan dalam jangka waktu pendek dan panjang.

Berdasarkan hasil penelitian adapun saran yang dapat diberikan terkait dengan manajemen kelelahan yaitu diharapkan melakukan pendidikan dan pelatihan mengenai K3 secara berkala kepada seluruh pihak yang terkait di RSU Haji Surabaya, khususnya perawat di Instalasi Rawat Inap. Selain itu, membentuk suatu tim yang mengontrol keadaan dan lingkungan kerja di rumah sakit sehingga beban tambahan dari lingkungan kerja baik faktor fisik, faktor kimiawi, faktor biologis, faktor fisiologis atau ergonomis dapat diatur dan dikelola sehingga tidak menambah beban kerja perawat. Menurut Suma'mur (2009), bahwa beban akibat lingkungan kerja merupakan beban tambahan bagi pekerjaan.

Selain itu, pihak rumah sakit sebaiknya melakukan pemeriksaan kesehatan kepada perawat. Pemeriksaan kesehatan bertujuan untuk mengetahui kelelahan kerja yang dialami perawat melalui pengukuran kelelahan secara objektif. Adapun pengukuran kelelahan kerja secara objektif adalah pengukuran konsumsi oksigen, pengukuran denyut nadi, pengukuran kadar asam laktat, dan pengukuran waktu reaksi. 
Terkait dengan asupan kalori, pihak rumah sakit sebaiknya tidak hanya memberikan snacks pada hari-hari tertentu saja sebab bisa saja ada perawat yang tidak dinas pada hari tersebut sehingga tidak memperoleh snacks, sebaiknya juga pemberian snacks dilakukan setelah perawat bekerja selama 2 jam sebab pada saat tersebut persediaan kalori sudah habis (Suma'mur, 2009). Adapun snacks yang dapat diberikan menurut Suma'mur (2009), adalah teh manis, bubur kacang hijau, pisang, buah-buahan segar, minuman dingin, dan lain-lain.

Berdasarkan hasil penelitian bahwa sebagian besar perawat mengalami kelelahan kerja kategori sedang sehingga perawat melakukan rekreasi secara rutin yang di koordinasi oleh pihak Instalasi Rawat. Menurut Suma'mur (2009), bahwa rekreasi merupakan salah satu cara untuk mengurangi kelelahan kerja. Selain mengadakan rekreasi, pihak rumah sakti sebaiknya melakukan kegiatan yang bersifat sosial yang bisa menjadi sarana berkumpulnya perawat Instalasi Rawat Inap. Hal ini bisa memberikan penyegaran bagi perawat dan lebih mempererat hubungan antar perawat.

Terkait dengan shift kerja, sebaiknya pihak rumah sakit lebih memperhatikan rotasi shift kerja. Menurut Siswanto (1991), bahwa shift kerja sebaiknya dilakukan dengan waktu kerja sependek mungkin, misalnya 2-3 hari sekali. Hal ini sudah sesuai dengan sistem shift kerja di Instalasi Rawat Inap RSu Haji Surabaya yaitu melakukan shift kerja dengan rotasi 2-3 hari, namun berdasarkan daftar dinas masih ada beberapa perawat yang tidak mendapatkan libur akhir pekan dalam sebulan. Menurut Suma'mur (2009) dan Setyawati (2010), bahwa terdapat beberapa hal yang harus diperhatikan pada saat pengaturan shift kerja, salah satunya adalah tersedianya waktu libur akhir pekan minimal 2 kali dalam sebulan agar perawat memiliki waktu berkumpul bersama keluarga dan kehidupan sosial. Hal ini berhubungan dengan kondisi psikologis perawat. Adanya waktu bercengkerama dengan keluarga diharapkan mampu mengembalikan semangat dan kemauan serta motivasi kerja perawat. Menurut Setyawati (2010), bahwa kelelahan kerja dapat menurunkan prestasi dan motivasi kerja.

\section{SIMPULAN}

Berdasarkan hasil penelitian, diperoleh kesimpulan bahwa sebagian besar responden berumur 30-49 tahun, berjenis kelamin perempuan, masa kerja lebih dari 5 tahun, sudah menikah, memiliki status gizi normal, dan memiliki asupan kalori kategori kurang. Sebagian besar responden memiliki beban kerja fisik kategori sedang dan kelelahan kerja tingkat sedang.

Hasil penelitian menunjukkan bahwa terdapat hubungan searah dan kuat antara beban kerja fisik dan kelelahan kerja yang menandakan bahwa semakin tinggi beban kerja fisik, maka semakin tinggi pula tingkat kelelahan kerja yang akan dialami. Hasil penelitian juga menunjukkan ada perbedaan tingkat kelelahan kerja berdasarkan beban kerja fisik.

Manajemen kelelahan kerja adalah salah satu upaya yang dapat dilakukan untuk mencegah dan menghambat peningkatan kelelahan kerja, baik berjangka waktu pendek maupun berjangka waktu panjang. Saran yang dapat diberikan kepada RSU Haji Surabaya dan perawat di Instalasi Rawat Inap antara lain melakukan pengukuran kelelahan kerja secara objektif, pemberian snacks, mengadakan rekreasi, pengaturan ulang shift kerja sesuai dengan aturan dan syarat-syarat ketentuan shift kerja.

\section{DAFTAR PUSTAKA}

Dewi, H.P.A./Beberapa Faktor yang Berhubungan dengan Kelelahan Kerja pada Perawat Rumah Sakit Adi Husada Undaan Wetan Kota Surabaya. http://adln.lib.unair.ac.id/go.php?id=gdlhub-gdls1-2010-dewihening-11518-fkm171-b.pdf(sitasi 9 Maret 2013)

Dianasari, E./Perbedaan Keluhan Kelelehan pada Perawat Berdasarkan Unit Kerja di RSU Kaliwates Jember (Studi Pada Unit Rawat Jalan, Unit Rawat Inap, dan Unit Gawat Darurat).http://adln.lib. unair.ac.id/go.php?id=gdlhub-gdl-s1-2014dianasarie-37114-7.-abstr-k.pdf (sitasi 9 Maret 2015)

Doheny, M.O., C.B. Cook, dan M.C. Stopper. 1997. The Discipline of Nursing: An Introduciton. $4^{\text {th }}$ edition. Stamford, Conn: Appleton \& Lange.

Hariyati, M. Pengaruh Beban Kerja terhadap Kelelahan Kerja pada Pekerja Linting Manual di PT. Djitoe Indoensia Tobacco Surakarta.http:// www.eprints.uns.ac.id/id/eprint/8474 (sitasi 24 Februari 2015)

Maharja, R. 2015. Hubungan Beban Kerja Fisik, Shift Kerja, dan Asupan Kalori dengan Kelelahan Kerja. Skripsi. Surabaya; Universitas Airlangga.

Nawawinetu, E.D. 2012. Thermal Stress. Surabaya: Departemen Kesehatan dan Keselamatan Kerja Fakultas Kesehatan Masyarakat Universitas Airlangga. 
Nugraha, A./Kelelahan Pada Pekerja di Instalasi Gizi Rumah Sakit (Studi pada Pekerja Instalasi Gizi RS. Pusdik Gasum Porong). http://adln.lib.unair. ac.id/go.php?id=gdlhub-gdl-s1-2010-nugrahand10987 (sitasi 9 Maret 2015)

Nurhayati, V.T./Hubungan Antara Karakteristik Individu dengan Tingkat Kelelahan Kerja Subjektif pada Perawat (Studi di Instalasi Rawat Inap Rumah Sakit Umum Unit Swadana Daerah Dr. R. Sosodoro Djatikoesoemo Kab. Bojonegoro. http://adln.lib.unair.ac.id/go.php?id=gdlhub-gdls1-2006-nurhayativ-2457 (sitasi 9 Maret 2015)

Nurmianto, E. 1998. Ergonomi: Konsep Dasar dan Aplikasinya. Jakarta: Guna Widya.

Perwitasari, D. dan A.R. Tualeka, 2014. Faktor yang Berhubungan dengan Kelelahan Kerja Subjektif Pada Perawat di RSUD DR. Mohommad Soewandhi Surabaya. The Indonesian Journal of Safety, Health And Environment, 1(1): 15-23.

Potter, P.A. dan A.G. Perry. Fundamental of Nursing. $7^{\text {th }}$ Edition. (diterjemahkan oleh Adrina Ferderika Nggie). Singapore.

Rahmawati, M./Beberapa Faktor yang Berhubungan Dengan Keluhan Subjektif Pada Perawat di RSUD Dr. Harjono Kabupaten Ponorogo. http:// adln.lib.unair.ac.id/go.php?id=gdlhub-gdl-s12006-rahmawatim-2607 (sitasi 9 Maret 2015).

Ramayanti, R. 2015. Hubungan Status Gizi dan Beban Kerja terhadap Kelelahan Kerja (Studi Pada Tenaga Kerja PT. Hikmah Sejahtera Bagian Catering Hikmah Food Surabaya. Skripsi. Surabaya; Universitas Airlangga.

Santoso, G. 2014. Ergonomi: Manusia, Peralatan, dan Lingkungan. Jakarta: Prestasi Pustaka Publisher.
Sari, A.R./Hubungan Indeks Massa Tubuh (IMT) dan Asupan Kalori dengan Kelelahan Kerja pada Tenaga Kerja Wanita di PT Meermaid Textile (Mertex) Mojokerto.http://adln.lib.unair.ac.id/ go.php?id=gdlhub-gdl-s1-2014-sariastinr-33589 (sitasi 9 Maret 2015)

Setyawati, L. 2010. Selintas tentang Kelelahan Kerja. Yogyakarta: Amara Books.

Siswanto, A. 1991. Ergonomi. Surabaya: Balai Hiperkes dan Keselamatan Kerja Jawa Timur Departemen Tenaga.

Suma'mur. 2009. Higiene Perusahaan dan Kesehatan Kerja (Hiperkes). Jakarta: CV Sagung Seto.

Tarwaka. 2010. Ergonomi Industri: Dasar-dasar Pengetahuan Ergonomi dan Aplikasi di Tempat Kerja. Harapan Press. Solo.

Utami, A.R.D. Hubungan Antara Beban Kerja dan Intensitas Kebisingan dengan Kelelahan pada Tenaga

Kerja Pemeliharaan Jalan Cisalak Kota Serayu Indah Cilacap. http://www.lib.unnes. ac.id/18232/1/6450406011.pdf (sitasi 4 Maret 2015)

Wati, M. dan W. Haryono/Hubungan Antara Beban Kerja Dengan Kelelahan Kerja Karyawan Laundry di Kelurahan Warungboto Kecamatan Umbulharjo Kota Yogyakarta.http://download.portalgaruda. org/article.php?article $=123547 \&$ val $=5543$ ( sitasi 4 Maret 2015)

Zuliana, N./Hubungan Karakteristik Individu dan Faktor Pekerjaan terhadap Tingkat Perasaan Kelelahan Kerja Perwat Rawat Inap RSUD Dr. Iskak Tulungagung.http//adln.lib.ac.id/ go.php?id=gdlhub-gdl-s1-2013-zuliananim26993 (sitasi 9 Maret 2015) 